\title{
EU FUNDING PROGRAMS FOR CULTURAL TOURISM PROJECTS
}

\author{
Tijana Radojević, \\ Nikica Radović, \\ Jasna Petrović \\ Singidunum University, \\ Belgrade, Serbia
}

\begin{abstract}
:
The European Union (EU) has recognized and observed the results of activities in the tourism sector by following the developments and results in the field of various economic activities. In this regard, the "EU Tourism Development Strategy" has been created, alongside numerous projects and initiatives aimed at improving tourism. Therefore, the old projects have been redefined and new projects/funds formed with the aim of supporting and financing activities in the field of tourism, primarily cultural tourism, as well as the creative one. The aim of this paper is to provide an overview of the EU programs/funds that support the development of various fields, while focusing on individual programs/funds that take part in the improvement of tourism and shaping of the cultural tourism in Serbia.
\end{abstract}

Keywords:

European Union, tourism, cultural tourism, funds

\section{INTRODUCTION}

The interests of modern tourists are changing in keeping with an increase in technological literacy and the knowledge they possess, and therefore the forms of tourism that have specific interest, the socalled thematic tourism that encompasses different kinds of tourism such as, cultural tourism, city tourism, rural tourism, ecotourism, health tourism, nautical tourism and the like, are considered increasingly more attractive (Radović et al., 2017).

Cultural tourism, as an alternative form of tourism, represents a type of tourist activity in which a tourist has the basic motivation to learn, discover, consume and experience tangible and intangible cultural attractions/products on a tourist destination (UNWTO, 2018). According to Jovanović (2015), cultural tourism is characterized by certain specificities in relation to other types of tourism: it transports the wealth and diversity of places and cultures, creates a new tourism product, and minimizes environmental degradation. Cultural tourism builds and improves the market of cultural values and emphasizes the quality and authenticity of visitors' experiences at the destination. Cultural resources are an important heritage and a driver of cultural tourism development, and they include: ethnographic, artistic, specialized and other types of museums, archaeological sites, 
historical sites, ethno-parks, music centers, sculptures, exhibitions, galleries, old crafts and handicrafts, folk songs and dance, local manifestations, folk costumes, as well as the national gastronomic offer (Radović et al., 2017), all based on the values, customs, traditions of the people of a particular area / destination.

\section{TOURISM INDUSTRY IN THE WORLD AND EU}

From a global aspect, the tourism industry is considered the fastest-growing economic activity, as confirmed by data according to which it accounts for $10 \%$ of the world GDP, that is, US \$ 1220 trillion in revenues in 2016, in addition to the fact that every 11th inhabitant in the world is employed in the tourism industry (UNWTO, 2017). Bearing in mind that the tourism industry is a rapidly growing activity, with the possibility of attracting new investments, tourism can most quickly activate new jobs and engage people from various activities (Radović, Čigoja Piper, 2016).

Europe is the most popular tourist destination in the world, with a market share of 50\% for the year 2016 (WTTC, 2017). In the European Union (EU), tourism as a business activity records constant GDP growth and well as a rising number of visitors. Namely, in the course of 2017, the EU countries "hosted" 538 million tourists, which accounts for about $40 \%$ of overall tourist trends in the world. According to WTTC data (2017), the tourism sector employs almost 26.5 million people in 2 million enterprises (SMEs) who create around 10.2\% of GDP, accounting for $6 \%$ of total EU exports, 375.1 billion euros. On the basis of these indicators, it may be concluded that tourism is a third activity in the EU, right after the trade-distribution and construction sector.

Figure 1. Tourism in the European Union

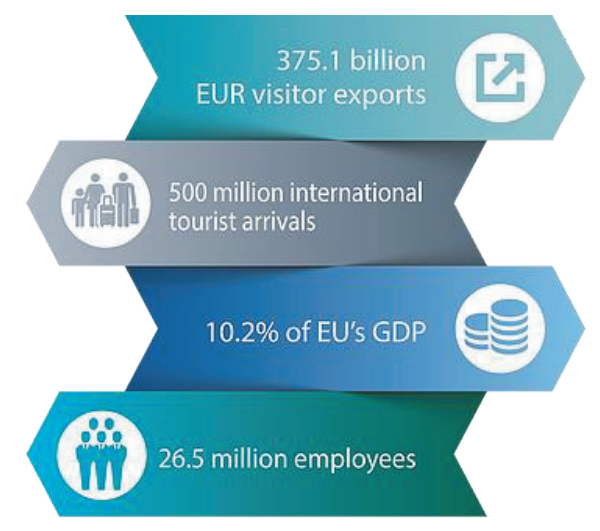

Source: WTTC (2017)

\section{EU STRATEGY IN THE FIELD OF CULTURAL TOURISM}

Despite all the growth parameters, the EU tourism industry faces many challenges every day, taking into account the inevitable trend following and adapting to the digital revolution, innovations, and the expectations of service users. In order to improve and develop the tourism industry in the EU, a Tourism Development Strategy entitled "Europe, World Tourism Destination Number 1 - A New Tourism Policy Framework for Europe" was created. This strategy defines four priority areas for engagement, namely: focus on competitiveness, promoting the development of sustainable, responsible and quality tourism, strengthening the image of Europe as a sustainable and high-quality destination, with heritage protection programs in tourist destinations and maximizing the potential of financial policies and instruments for the development of tourism in the EU. In this regard, the European Commission, in support of the EU Tourism Strategy 2014-2020, has established funds that help and support the development of the tourism sector and destination and product development 
activities. According to Richards (2005) "cultural tourism has a central role in the European tourism industry," bearing in mind the richness and tradition of the cultural heritage of the European continent.

Programmes established through EU funding include (EU Commission, 2015):

- European Fund for Strategic Investments

- European Regional Development Fund

- Cohesion Fund

- European Social Fund

- European Agriculture Fund for Rural Development (EAFRD)

- European Maritime and Fisheries Fund

- LIFE

- Horizon 2020

- COSME

- Creative Europe Programme

- Erasmus+

- Employment and Social Innovation (EASI), and some of them take part in funding activities in the sector of tourism and culture.

Figure 2. Programmes/funds of financing in the field of culture and education

\begin{tabular}{|c|c|c|}
\hline Area & MFF 2007-2013 & MFF 2014-2020 \\
\hline \multirow[t]{8}{*}{ Culture and Education } & $\checkmark$ European Culture Programme & $\checkmark$ Creative Europe Programme \\
\hline & $\checkmark$ Lifelong Learning Programme & $\checkmark$ Erasmus for All Programme \\
\hline & $\begin{array}{l}\text { (Erasmus, Leonardo da Vinci, } \\
\text { Comenius and Grundtvig) }\end{array}$ & \\
\hline & $\checkmark$ Erasmus Mundus & \\
\hline & $\checkmark$ Tempus & \\
\hline & $\checkmark$ Alfa & \\
\hline & $\checkmark \quad$ Edulink & \\
\hline & $\begin{array}{l}\checkmark \text { Programme for cooperation with } \\
\text { industrialised countries }\end{array}$ & \\
\hline
\end{tabular}

Source: Guide on EU Funding for the Tourism sector 2014-2020, EU Commission, 2015. pp.4

In 1987, the Council of Europe launched the Cultural Routes program in order to demonstrate the legacies of different countries and cultures in Europe and show their connection in a visible way. Through its programs / funds, the European Commission co-financed the development of cultural routes that help European and non-European tourists discover how Europeans have lived since ancient times. Therefore, from 1987 until July 2018, 33 different cultural routes have been created and financially supported: Santiago de Compostela Pilgrim Routes, (1987), The Hansa (1991), Viking Routes (1993), Via Francigena (1994), Routes of El legado andalusi (1997), Phoenicians' Route (2003), Pyrenean Iron Route (2003), European Route of Jewish Heritage (2004), European Mozart Ways (2004), Cluniac Sities in Europe (2005), Routes of the Olive Tree (2005), Via Regia (2005), Saint Martin of Tours Route (2005), TRANSROMANICA (2007), Iter Visit Route (2009), European Route of Cistercian Abbeys (2010), European Cemeteries Route (2010), Prehistoric Rock Art Trails (2010), European Route of Historic Thermal Towns (2010), Route of Saint Olav Ways (2010), European Route of Ceramics (2012), European Route of Megalithic Culture (2013), Huguenot and Waldensian trail (2013), ATRIUM (2014), Réseau Art Nouveau Network (2014), Via Habsburg (2014), Roman Emperors and Danube Wine Route (2015), European Routes of Emperor Charles V (2015), Destination Napoleon (2015), In the Footsteps of Robert Louis Stivenson (2015), Fortified Towns of the Grande Region (2016). (www.coe.int) 


\section{EU PROGRAMMES OF FUNDING PROJECTS IN THE FIELD OF CULTURAL TOURISM IN SERBIA}

As a pre-accession member, the Republic of Serbia has been given the opportunity to participate in the European Union's programs and on that occasion, she sees and realizes the institutions, policies, mechanisms of functioning, laws and application of the same in the countries of the European Union. The provisional agreement on participation in European Union programs was signed on November 22, 2004. In 2009, the Republic of Serbia submitted an application for EU accession and is obliged to make certain preparations and adjustments to the legislation, and carry out certain internal reforms. The start of cooperation began in March 2001 through CARDS, or the Community Assistance Program for Reconstruction, Development and Stabilization. CARDS was replaced in 2006 by the IPA Program that lasted until 2013. The IPA II program followed, which will bring Serbia 1.5 billion euros in donations from 2014 to 2020 (about 200 million euros a year). The IPA II program focuses on the most important areas that should facilitate Serbia's preparations for EU membership. Within the Instrument for Pre-Accession Assistance (IPA II), the EU finances certain projects in Serbia aimed at providing support to Serbian economy by ensuring the implementation of intellectual property rights, improving consumer protection, facilitating capacity building and institutional strengthening, export promotion and innovation within SMEs, through cross-border cooperation projects, as well as through auxiliary activities that bring together tourism potential, economic development, recognizing the attractiveness of tourism products, and positioning Serbia in the global tourism market. Activities in Serbia are implemented through the IPARD program that fovccuses on the diversification of farms and business development, along with the development of tourist facilities in order to expand economic activities in the field of rural tourism. Within the tourism product of rural tourism, certain segments related to the promotion and valorization of cultural intangible resources are also included. This also paves the way for a certain synergy of cultural and rural tourism, bearing in mind that the expectations of tourists in rural areas, besides the untouched nature and unique natural resources, also include the experience gained from the contact with traditional / ethical resources that make up the cultural intangible heritage of the Serbian people, and these include customs (Patron Saint of Family, on the UNESCO list of intangible heritage since 2015), traditional manifestations, traditional way of preparing food and drinks, a dance (Kolo, on the UNESCO list of intangible heritage from 2017), song, and so on. Through INTERREG IPA programs, Serbia, in cooperation with its partners, is working on achieving three main goals: promoting cross-border mobility of employees in the sector of culture, promoting transnational cultural and artistic mobility, and fostering intercultural dialogue (https://interreg.eu/list-of-programmes/).

Some of IPA INTERREG projects in which Serbia participates as a partner are:

- INTERREG III B TRANSROMANICA CrossCulTour programme that represents a joint heritage of the romantic era of nine European countries- France, Spain, Portugal, Germany, Austria, Slovakia, Italy, Serbia, Romania

- INTERREG V B ADRION - ADRIATIC IONIAN the program of the Adriatic-Ionian region represents activities within which, through innovative policies and management processes, the strengthening of European integration among the partner countries and the use of rich natural, cultural and human resources in the Adriatic and Ionian Sea region will increase the economic, social and territorial cohesion of the participating countries - Greece, Croatia, Italy, Slovenia, Albania, Bosnia and Herzegovina, Montenegro and Serbia

- INTERREG V B DANUBE (Austria, Bulgaria, Czech Republic, Germany, Croatia, Hungary, Romania, Slovenia, Slovakia, Bosnia and Herzegovina, Montenegro, Serbia, Moldova, Ukraine and the EU finance about 84 million EUR) INTERREG "Virtual and Cultural Tourism - ViCTour" (Tourist Association of Vukovar-Srem County, Tourism Organization of Vojvodina, Faculty of Economics in Subotica and European Affairs Fund of AP Vojvodina). The project is worth 924,327 euros, and the EU finances 85\% of it. It has been implemented since June 15, 2017 and will last until October 14, 2019, and the idea is to in this period develop a recognizable visual identity of the region, improve tourist promotion and offer, and improve visibility of tourist offer in the cross-border area. Srem, famous for the beauties of Fruska Gora, the historical and cultural value of the Fruska Gora monasteries, Sirmium and many other sights and monuments of culture, will be presented through virtual cultural routes, but also through a film shot using timelapse technique. Seven Srem Municipalities - Sid, Indjija, Sremska Mitrovica, 
Ruma, Irig, Stara Pazova and Pecinci, along with Sremski Karlovci, will have the opportunity to show the historical, cultural and tourist values of their heritage. All this will be achieved through the use of modern information and communication technologies that will be deliberately developed during the project. Through ViCTour, the cultural and natural heritage of the region will be presented in a modern way, and a number of tourist activities, study tours, education of tourist guides, as well as the purchase of modern IT equipment are envisaged (www.europa.rs).

The Republic of Serbia participates in the following EU programs, some of which support sustainable and cultural tourism (www.mei.gov.rs):

- Horizon 2020.

- Program for the competitiveness of small and medium-sized enterprises - COSME

- Program for employment and social innovations

- Erasmus+

- creative Europe

- Europe for citizens

- European health program III

- Fiscalis 2020

- Customs 2020

- eu civil protection mechanism

Through the COSME program Serbia is present in the projects "EuroVelo Routes" - EuroVelo6, EuroVelo11 and EuroVelo13, i.e. a European long-haul route network. The EU program "Iron Curtain Travel" is also interesting, as it represents the former division of Europe through the territory of states in the length of $6,800 \mathrm{~km}$, with the synergy of culture, history and sustainable tourism. In Serbia the most important are three main directions along the former "Iron Curtain": the Danube trail, as well as the tracks through the center of Serbia to the Danube, Sava, Tisa, Drina, Morava and Ibar Rivers. There are important monuments of cultural heritage from ancient, medieval, Ottoman, Baroque times, as well as beautiful natural resources.

The Creative Europe program consists of the sub-programs of the Culture and Media Program and are intended for the sectors of culture and media sectors. The idea behind these programs is to support the cultural centers of the EU member states and publishers in order to expand the initiative of translating literary works and to enable the connection between creative and cultural industries, with the encouragement of new / young artists in the field of literature, painting, audiovisual and digital technologies. By the beginning of 2018, more than 95 cultural projects in Serbia were funded through this program, with a value of more than 4.5 million euros (www.europa.rs). Through this program, the project "European capital of culture Novi Sad 2021" will be funded, which will contribute to better targeting in Novi Sad and Serbia on the tourist map.

When it comes to "Cultural Route" projects supported and funded by the Council of Europe and the European Parliament, Serbia is present in: TRANSROMANICA, The Iter Vitis Route, European Cemeteries Route, Réseau Art Nouveau Network and The Roman Emperors and Danube Wine Route (www.coe.int). At present, the Routs $4 \mathrm{U}$ competition is trending, inviting interested parties to apply with new projects aimed at expanding the offer of branded products, small and medium-sized enterprises, local producers, craftsmen, artists etc., which are linked to the Council of Europe's certified Cultural Routes. The competition is aimed at creating sustainable and innovative tourist offers with a focus on the specific needs of the local area, crossborder regions or macro-regions. It will also support sustainable development in the field of creative industries and the tourism sector; promote cooperation in the field of culture between local, national and international participants in accordance with the principles of the Council of Europe Framework Convention on the value of cultural heritage for society - the Faro Convention (www.kultura.gov.rs).

In the field of tourism, the European Commission created the program "The Network of Exceptional Destinations of Europe - EDEN”. The EDEN project promotes destinations for sustainable tourism development in member states and EU membership candidate countries. It is conducted annually with a topic chosen by the European Commission, and for 2017, for which the competition was on "cultural tourism" - "Tourism and local non-material cultural heritage ", the winner is Novi Pazar. Novi Pazar submitted its candidacy and 
won owing to its rich multicultural heritage that includes monuments on the UNESCO list - the medieval complex of Stari Ras with the Church of the Holy Apostles Peter and Paul and the monasteries Sopoćani and Đurđevi Stupovi, which are part of the Cultural Route of the Council of Europe TRANSROMANICA, then the sights from the Ottoman period - Novi Pazar fortress with old bazaar, Altun alem and Lejlek mosque, Isa beg's hamam and many other sites and contents that reflect the richness of tradition (www.europa.rs).

\section{CONCLUSION}

Serbia abounds in cultural and historical material and non-material heritage from ancient times to contemporary works of art. Unfortunately, the tourist offer of these resources, which cultural tourism is based on, is not sufficiently developed. If we take into consideration the fact that cultural tourism destinations attract visitors with higher purchasing power, that cultural tourism trips are organized several times a year, and such destinations exclude seasonality as a characteristic, everything points to economic advantages and promotes the idea to improve cultural tourism in Serbia, with a view to developing and ensuring a better position of Serbia on the tourism market. Cooperation with the EU Mission in Serbia and partnerships with neighboring countries can contribute to improving the funding of activities and projects that are valued in the context of cultural tourism as a tourist product of importance to the Tourism Development Strategy of the Republic of Serbia from 2016-2025.

In keeping with the EU decision, 2018 was declared the European Year of Cultural Heritage. The aim of this project is to encourage the exchange and improvement of European cultural heritage, raise awareness of our common past and values and enhance the sense of belonging to the common European area. Serbia is not a member of the EU, but there are certainly a number of activities and projects in which we, as a pre-accession member, are involved and which will contribute to raising the general public's awareness of the importance of the material and non-material cultural heritage that we have had from prehistory to this day.

\section{REFERENCES}

European Commission. (2016). Guide on EU funding for the tourism sector (2014-2020). Luxembourg: Publications Office.

European Commission. (2017). Serbia. https://ec.europa.eu/growth/tools-databases/eden/destinations/serbia_en (accessed 23.07.2018)

Jovanović, V.(2015). Tematski turizam. Beograd: Univerzitet Singidunum.

Radović, N. Čigoja Piper, D. (2016). Tourism as Puzzle Improvement of Creative Economy. In Conferences Proccedings: SITCON 2016 (pp.33-36). Belgrade: Singidunum University. DOI:10.15308/Sitcon-2016-33-36

Radović, N., Stevanić, B., Stojanović, N., \& Radović, M. (2017). Digitalni mediji u funkciji unapređenja kulturnog turizma. In Conferences Proccedings: SINTEZA 2017 (pp.395-399). Beograd:Univerzitet Singidunum. DOI:10.15308/Sinteza-2017-395-399

Richards, G. (2005). Cultural tourism in Europe. Netherlands,Arnhem: ATLAS.

UNWTO (2017). Tourism Highlights. Madrid:World Tourism Organization.

UNWTO (2018). Tourism and Culture Synergies. https://www.e-unwto.org/doi/pdf/10.18111/9789284418978 (accessed 23.07.2018)

World Travel \& Tourism Council (2017). Travel \& Tourism Economic Impact 2017 European Union. London: WTTC

www.coe.int/en/web/cultural-routes/serbia (accessed 24.07.2018)

www.europa.rs (accessed 23.07.2018)

https://interreg.eu/list-of-programmes/ (accessed 23.07.2018)

www.kultura.gov.rs (accessed 24.07.2018)

www.mei.gov.rs (accessed 23.07.2018) 